\title{
Sosiaalisen median hyödyntäminen nuorten palvelujen yhteiskehittämisessä
}

\author{
Harri Jalonen, Jussi Kokkola, Valtteri Kaartemo \& Miika Vähämaa
}

\section{ABSTRACT \\ Using social media in co-creating public services}

Co-creation assumes an interactive and dynamic relationship where value is created at the nexus of interaction. Co-creating value is challenging with marginalized youths. In this article, social media is seen as an underutilized resource for developing services. This article approaches social media as a context from which it is possible to derive information that would otherwise be unattainable. Using data from a Finnish discussion board, this article answers the following question: How can the experiences of socially withdrawn youth shared on social media be used to enrich the knowledge base on service co-creation processes? The empirical data consist of messages on the Hikikomero discussion forum, which were analysed using a combination of unsupervised machine learning and discourse analysis. The results show that social media provides a window into the everyday lives of socially withdrawn youths, offering information that could be used to develop public services.

Keywords: co-creation, value creation, social media

\section{JOHDANTO}

Nuoren syrjäytyminen on inhimillinen tragedia, jolla on yhteiskunnallisia seurauksia. Vaikka ilmiön syistä ollaan montaa mieltä, yhteistä näkemyksille on se, että syrjäytyminen on prosessi, jossa nuoret kokevat osattomuuden ja voimattomuuden tunnetta tavalla, joka vaikeuttaa heidän kiinnittymistään koulu- ja työelämään (Vanttaja ym. 2019) sekä laajemmin yhteiskuntaan
(Ilmakunnas ym. 2015). Riippumatta siitä nähdäänkö syrjäytyminen nuoren itsensä syynä, kapinointina valtakulttuuria vastaan, vallankäytön epätoivottuna sivutuotteena vai palvelujärjestelmän kyvyttömyytenä tarjota riittävästi tukea (Suutari 2001), kyse on yhteiskunnallisesta haasteesta, joka velvoittaa etsimään ratkaisuja - ei vähiten siksi, että Suomessa on OECD:n selvityksen mukaan mielenterveydellisten ongelmien ja päihteiden väärinkäytön vuoksi syrjäytyviä nuoria monia muita maita enemmän (Kups ym. 2019).

Ongelma on tiedostettu ja myös tahtoa ongelman ratkaisemiseksi löytyy. Esimerkiksi pääministeri Sanna Marinin hallituksen hallitusohjelmassa esitetään nuorten syrjäytymistä ehkäiseviksi keinoiksi muun muassa seuraavia asioita: lapsi- ja nuorisopoliittisen ministerityöryhmän perustaminen, nuorten koulukuntoisuuden yksilöllisen arvioinnin toimintamallin rakentaminen, etsivän nuorisotyön ja työpajatoiminnan taloudellisten ja toiminnallisten edellytysten vahvistaminen sekä lapsi- ja nuorisolähtöinen budjetointi. Nuorten osallisuutta pyritään edistämään vahvistamalla koulujen ja oppilaitosten demokratia- ja ihmisoikeuskasvatusta sekä pitämällä huolta koulujen oppilas- ja opiskelijakuntatoiminnasta.

Nuorten osallistaminen on linjassa yhteiskehittämiseksi (co-creation) kutsutun ja erityisesti julkisten palvelujen yhteydessä suosituksi tulleen toimintaorientaation kanssa. Julkisten palvelujen yhteiskehittämisellä tarkoitetaan eri toimijoiden tiivistä yhteistyötä ja erityisesti käyttäjien osallistamista palvelujen toteuttamiseen niiden ideoinnista ja suunnittelusta aina toimeenpanoon ja arviointiin asti (esim. Voorberg ym. 2014, Brandsen ym. 2018, Osborne 2018). Yhteiskehittäminen edellyttää siihen osallistuvilta aktiivisuutta. Nuorten syrjäytymisen ehkäiseminen yhteiskehittämisen keinoin on erityisen 
vaativaa, sillä kyse on sellaisten nuorten osallistamisesta, jotka jo lähtökohtaisesti suhtautuvat osallistumiseen penseästi. Vaarana on, että yhteiskehittäminen jää syrjäytyvien nuorten kohdalla kauniiksi puheeksi ilman mahdollisuuttakaan realisoitua toimiviksi käytännöiksi. Aktiivisimmat nuoret pystyvät osallistumaan yhteiskehittämisen eetokseen, mutta kaikkein huonoimmassa olemassa olevien ääni jää helposti kuulematta. Artikkelin lähtökohtana on ajatus siitä, että sosiaalista mediaa voidaan hyödyntää syrjäytymisvaarassa olevien nuorten kuulemisessa.

\section{TUTKIMUSTEHTÄVÄ}

Syrjäytyminen ei tapahdu, eikä sitä myöskään ehkäistä tyhjiössä, sillä kyse on monien tekijöiden yhteisvaikutuksesta (Bowker ym. 2016). Nuorten syrjäytymisestä on muodostunut sitkeä ongelma varsinkin taloudellisesti kehittyneissä yhteiskunnissa (esim. Kato ym. 2012). Yhtenä tekijänä voidaan pitää kaikkialle levinnyttä (ubiquitous) digitalisaatiota, joka muokannut myös nuorten arkea ennakoimattomalla tavalla (Ransbotham ym. 2016). Ei ole liioittelua sanoa, että monet niistä ilmiöistä, joista sosiologit ovat kiinnostuneita tapahtuvat nykyään sosiaalisen median alustoilla. Sosiaalisessa mediassa sana on vapaa ja sitä käytetään moniin tarkoituksiin, kuten mielipiteiden polarisoimiseen (Sunstein 2017), väärän ja harhaanjohtavan tiedon levittämiseen (Vousoughi ym. 2018) sekä poliittisen propagandan julistamiseen (Woolley \& Howard 2018). Nettiin on syntynyt alakulttuureita, jotka saattavat näyttäytyä perinteisen valtajärjestelmän näkökulmasta vierailta ja joskus myös pelottavilta. Nuorten tietokonepelaaminen on esimerkki toiminnasta, johon liittyy erilaisia stigmoja (Meriläinen 2020). Erityisesti suosittujen taistelupelien koetaan vahingoittavan nuorten mieliä ja antavan haitallisia käyttäytymismalleja myös tosielämän konfliktitilanteisiin (Jalonen 2019b).

Artikkelissa tunnustetaan yhteiskehittämisen ideaalin ja todellisuuden välinen kuilu tilanteissa, joissa kehitettävien palvelujen käyttäjinä ovat nuoret, jotka ovat syystä taikka toisesta huonosti kiinnittyneitä tavanomaisiin ja yleisesti hyväksyttyinä pidettyihin yhteiskunnallisiin instituutioihin. Toisaalta artikkelissa tunnistetaan syr- jäytymisilmiöön liittyvät jännitteet ja uskotaan, että monimuotoista ja haitallista ilmiötä vastaan kannattaa taistella usealla rintamalla. Uskomme myös, että yhteiskehittämistä voidaan tukea, vaikka kehittämisen osapuolina olisikin toimijoita, jotka suhtautuvat yhteiskehittämiseen nuivasti. Etsimme artikkelissamme vastausta seuraavaan kysymykseen: Voidaanko yhteiskunnallisista instituutioista syrjässä olevien nuorten sosiaalisessa mediassa jakamia kokemuksia hyödyntää palvelujen yhteiskehittämisen tietoperustan rikastamisessa? Kohdistamme huomiomme erityisesti nuorten kokemuksiin sosiaali- ja terveyspalveluista (myöh. 'sote').

Voorbergin ym. (2014) jaottelua mukaillen olemme kiinnostuneita erityisesti yhteiskehittämisen alku- ja loppupäästä eli ideoinnista ja arvioinnista. Artikkelimme empiirinen aineisto koostuu ylilauta.org-keskustelufoorumin Hikikomero-vertaistukiryhmän viesteistä ja keskusteluista. Uskomme, että kaikkein hankalimmin tavoitettavan kohderyhmän asenteet, puhetavat ja tunteet palveluntarjoajia kohtaan jäävät helposti huomiotta palvelujen kehittämisessä. Artikkeli tuottaa uutta tietoa sosiaalisen median hyödyntämisestä nuorten osallistamisessa palvelujen yhteiskehittämiseen.

\section{SOSIAALINEN MEDIA JA PALVELUJEN YHTEISKEHITTÄMINEN}

Nuoret ovat sosiaalisen median suurkuluttajia. Esimerkiksi Tilastokeskuksen vuoden 2017 vapaa-aikatutkimuksen mukaan vain yksi sadasta alle 24-vuotiaasta suomalaisesta kertoi pidättäytyvänsä sosiaalisen median seuraamisesta. Sosiaalista mediaa käytetään moniin tarkoituksiin, ja sen käytöstä on todettu olevan sekä hyötyä että haittaa. Artikkelin tutkimustehtävän kannalta relevantteina hyötyinä on raportoitu muun muassa sosiaalisten suhteiden ylläpitäminen (Jordán-Conde ym. 2014), emotionaalisten siteiden vahvistaminen (Reich 2010), identiteetin rakentaminen ja ilmaiseminen (Boyd 2008), yksinäisyydentunteen vähentäminen (Yang \& Brown 2013), ystävyyssuhteiden laadun parantaminen (Valkenburg \& Peter 2009), terveyttä ja hyvinvointia koskevan tiedon hankinta ja vertaistuen saaminen (Robinson ym. 2016) sekä yhteiskunnallinen vaikuttaminen ja aktiivisen kansalaisuuden toteuttaminen (Weinstein 2014). 
Vastaavasti ongelmiksi on tunnistettu someriippuvuus (Davila ym. 2009), nettikiusaaminen (Christofides ym. 2012), kognitiivinen ja emotionaalinen pahoinvointi (Kross ym. 2013), sosiaalisen vertailun aikaansaamat psykologiset ongelmat (Jelenchick ym. 2013), pelko ulkopuoliseksi jäämisestä (Oberts ym. 2017), altistuminen epäterveellisille elämäntavoille (Dunlop ym. 2015), riski huonoon seuraan ajautumisesta (Seko ym. 2015) sekä yhteiskunnallisten mielipiteiden polarisoituminen (Keating \& Melis 2017). Jo lyhyt katsaus kirjallisuuteen osoittaa, että sosiaalinen media tarjoaa 'ikkunan' nuorten arkeen. Katsomme tässä artikkelissa, että avautuvaa näkymää voidaan hyödyntää erityisesti syrjäytymisvaarassa oleville nuorille suunnattujen palvelujen yhteiskehittämisessä.

Yhteiskehittämisessä on kyse eri toimijoiden välisessä interaktiivisessa ja dynaamisessa vuorovaikutuksessa tapahtuvasta arvonluonnista (Osborne 2018, 225). Parhaimmillaan yhteiskehittämisessä palvelun loppukäyttäjällä on sananvaltaa kehitettävän palvelun sisältöön, laatuun ja saatavuuteen. Yhteiskehittäminen nähdään tavanomaisesti vastauksena palvelujen käyttäjien tarpeiden huomioimiseen (laatuargumentti), kansalaisten osallistamiseen (demokratiaargumentti), resurssien tehokkaaseen hyödyntämiseen (tuottavuusargumentti), uusien ja luovien ideoiden tuottamiseen (innovaatioargumentti) sekä palvelujen yleiseen hyväksyttävyyteen (legitimiteettiargumentti) (ks. esim. Brandsen ym. 2018, Jalonen 2019a). Toisaalta yhteiskehittäminen on vaativaa toimintaa, jossa onnistuminen on kaikkea muuta kuin varmaa. Yhteiskehittämisen ongelmiksi on todettu muun muassa julkishallinnon tilintekovastuun hämärtyminen, transaktiokustannusten nousu, demokratian heikentyminen ja eriarvoisuuden lisääntyminen (ks. tarkemmin Steen \& Tuurnas 2018).

Yhteiskehittäminen erotetaan yhteistuotannosta (co-production, esim. Bovaird 2007) useimmiten sen perusteella, miten vahvasti palvelujen käyttäjät osallistuvat jo palvelujen ideointivaiheeseen. Yhteistuotanto-orientoituneessa toiminnassa yhteistyötä tehdään palvelujen tuotannossa, mutta palvelun sisältö on märitelty julkisen organisaation toimesta, kun taas yhteiskehittämisessä palvelujen käyttäjät tai heidän edustajansa osallistuvat myös tavoitteenmäärittelyyn ja palvelujen sisältöjen muotoilemiseen.
Yhteiskehittäminen jaetaan tyypillisesti toisiaan seuraaviin vaiheisiin, kuten alullepanoon (coinitiation), suunnitteluun (co-design), tuotantoon (co-production) ja arviointiin (co-evaluation) (ks. Fox ym. 2019). Voorbergin ym. (2014) mukaan palveluiden käyttäjät voivat osallistua yhteiskehittämiseen aloitteentekijöinä, muotoilijoina ja toteuttajina. Käyttäjien vaikutusvalta on lähtökohtaisesti sitä suurempi, mitä aikaisemmassa vaiheessa he kehittämiseen osallistuvat.

Yhteiskehittämisestä on tullut suosittua, mutta näyttö sen tuloksellisuudesta ei ole vakuuttavaa. Esimerkiksi Voorberg ym. (2014) arvioivat 122 empiirisen tutkimuksen perusteella, että vaikka yhteiskehittämisen (ja yhteistuotannon) tavoitteet on pääsääntöisesti hyvin jäsennetty ja myös kehittämistä edistävät ja estävät tekijät tunnetaan, empiirinen näyttö yhteiskehitettyjen palvelujen vaikuttavuudesta jää puutteelliseksi. Todennäköistä on, että kuva olisi huomattavasti lohduttomampi, jos analyysi rajattaisiin nuorten syrjäytymistä ehkäisevien palvelujen yhteiskehittämiseen. Vaikuttavuuden osoittamisen ohella ongelmana olisi luultavasti myös itse prosessi eli palvelujen kohderyhmään kuuluvien osallistaminen. Yhteiskehittämiseen on sisäänrakennettu oletus aktiivisesta palvelunkäyttäjästä, jolla on sekä intressi että resursseja osallistua yhteiskehittämiseen. Usein näin onkin, mutta syrjäytyneiden nuorten kohdalla ajatus aktiivisesta osallistumisesta näyttää puhdasoppiselta oksymoronilta, retoriselta rakennelmalta, jossa yritetään yhdistää kaksi vastakkaista käsitettä.

Pitäisikö siis yhteiskehittäminen unohtaa syrjäytyneille nuorille suunnatuissa palveluissa vai onko kyse ennemminkin siitä, että yhteiskehittämisessä pitäisi ottaa nykyistä syvällisemmin huomioon osallistettavien nuorten tarpeet, toiveet ja pelot? Kannatamme jälkimmäistä lähestymistapaa, jonka toteuttaminen edellyttää nähdäksemme ontologista sitoutumista (mitä yhteiskehittäminen on?) epistemologisin (mistä tiedämme, että yhteiskehittäminen on hyväksi?) ja metodologisin (miten yhteiskehittämistä voidaan edistää?) seurauksin.

Ontologisen sitoumuksen näkökulmasta yhteiskehittämisen yhtenä kantavana ideana on se, että palvelunkäyttäjä on oman arkensa paras asiantuntija. Tämä on itsestään selvältä vaikuttava toteamus, jolla on kuitenkin käytännön 
merkitystä, sillä se ohjaa huomiota yhteiskehittämisen liikkeellepanevaan voimaan. Ei ole yhdentekevää, paikantaako yhteiskehittämisen kohteen palvelua tarjoava 'systeemi' vai palvelun käyttäjä. Ongelmiin ja vaikeuksiin keskittyvässä puuteperustaisessa lähestymistavassa (deficit-based approach, ks. esim. Dinishak 2016) palvelujen käyttäjät nähdään passiivisina kohteina ja palveluntarjoajan tehtäväksi jää puutteen poistaminen. Kun yhteiskehittämistä lähestytään voimavaraperustaisesti (asset/strengthbased approach, esim. Baron ym. 2019), yhteiskehittämisen laukaisevana tekijänä ei ole puute jostakin vaan mahdollisuus johonkin. Voimavaralähtöisen yhteiskehittämisen ytimessä on ajatus siitä, että palvelujen käyttäjillä on toimijuutta (agency, esim. Emirbayer \& Mische 1998). Toimijuus konkretisoituu taitoina, kokemuksina ja suhteina, joita käyttäjät voivat tarpeen mukaan aktivoida omaksi ja yhteisönsä hyödyksi. Voimavaralähtöisessä yhteiskehittämisessä ei kysytä, mikä käyttäjiä vaivaa ( what is the matter with them?) vaan mikä on ihmisille merkityksellistä (what matters to people?). Huonoimmissakin olosuhteissa elämällä on aina merkityksensä (Frankl 1946). Voimavaralähtöinen yhteiskehittäminen merkitsee samalla luopumista siitä ajatuksesta, että heikosti opiskelu- ja työelämään kiinnittyvä nuori olisi passiivinen kaikilla elämän osa-alueilla ja kyvytön toimimaan oman arkensa kokemusasiantuntijana. Franklin (emt.) hengessä voidaan ajatella, että voimavaralähtöisessä yhteiskehittämisessä on kysymys syrjäytyneelle nuorelle tarjottavasta tuesta elämän merkityksellisyyden etsimisessä.

Voimavaraperustaisen lähestymistavan epistemologisena seurauksena näemme sen, että yhteiskehittämisen onnistumisen arvioinnin tulee tapahtua käyttäjälähtöisesti. Yhteiskehittäminen on pohjimmiltaan arvonluontia (esim. Hardyman ym. 2015, Brandsen ym. 2018, Osborne 2018), jossa arvo syntyy toiminnan tuotosten ja siihen kohdistettujen uhrausten erotuksesta. Yhteiskehittämisellä luotu palvelu ei ole arvon synonyymi vaan 'väline', joka 'kutsuu' sen käyttäjän arvonluonnin prosessiin. Palvelun arvoa ei voida vangita sen ominaisuuksiin, sillä sen arvo paljastuu vasta käytössä (value-in-use) ja tietyssä kontekstissa (value-in-context). Se, mikä toimii yhdellä ja yhdessä ympäristössä, ei välttämättä ole arvokasta toiselle toisessa ympäristössä (ks. tarkemmin palvelun käyttöarvosta ja arvonluonnin kontekstista esim. Vargo \& Lusch 2017). Yhteiskehittämisellä luodun palvelun arvo voi ilmetä yksilöiden ja yhteisöjen tarpeiden (need) tyydyttämisenä, yksilöiden ja yhteisöjen hyvinvoinnin (well-being) lisääntymisenä sekä yksilöiden ja yhteisöjen kyvykkyyksien (capacity) kasvamisena (Osborne 2018). Käyttötilannetta ja -kontekstia korostava näkökulma on hyödyllinen, sillä se auttaa ymmärtämään niitä moninaisia arvottamisen tapoja (Boltanski \& Thévenot 2006, Jalonen ym. 2020), jotka tekevät palveluista käyttäjilleen merkityksellisiä. Koska yhtä ja samaa palvelua voidaan haluta monesta eri syystä ja vastaavasti hyvinkin erilaisten palvelujen hankkimista voidaan perustella samankaltaisin syin, tärkeää on, että palveluja arvioidaan niiden ominaisuuksien sijaan käyttäjien tarpeiden ja odotusten perusteella. Tämä on ensiarvoisen tärkeää erityisesti syrjäytyneiden nuorten kohdalla, sillä osalla nuorista syrjäytyminen on taistelua oman arvomaailman näkökulmasta vieraiksi koettuja yhteiskunnan arvoja vastaan.

Metodologisesti mielenkiintoisin kysymys kohdistuu niihin tapoihin, joilla keskeneräisesti yhteiskuntaan kiinnittyneitä nuoria voidaan osallistaa yhteiskehittämiseen. Tehtävä on vaikea, sillä syrjäytymisen logiikkaan kuuluu sosiaalinen vetäytyminen ja sivulliseksi jättäytyminen. Esimerkiksi Kulmala (2004) on kuvannut syrjäytymistä toiseuden (otherness, ks. tarkemmin Bauman 2000) käsitteen avulla prosessiksi, jossa syrjäytyneet näkevät itsensä erilaisina suhteessa 'normaaleiksi' pitämiinsä ihmisiin. Toiseus ei jää Kulmalan (2004) mukaan vain erilaisena olemiseksi vaan näkyy myös toiminnassa ja niissä kertomuksissa, joita toiseutta kokevat rakentavat. Kulmalan havainto saa tukea muun muassa Haasiolta (2015), joka on tutkinut sosiaalisesti vetäytyneiden nuorten informaatiokäyttäytymistä. Chatmania (1991) hyödyntäen Haasio $(2015,124)$ havaitsi, että toiseutta tuntevat nuoret muodostavat vertaistensa kanssa virtuaalimaailmassa 'pienen maailman', jonka puitteissa he samaistuvat toisiinsa, vaikka viestisivätkin anonyymisti. Haasion $(2015,124)$ mukaan arjen ongelmatilanteet ja sosiaaliset rajoitteet toimivat pienessä maailmassa yhteenkuuluvuuden tunnetta vahvistavana tekijänä. Verkossa jaettavat sisällöt tarjoavat mielenkiintoisen näkymän syrjäytyneiden tai syrjäytyneiksi miellettyjen nuor- 


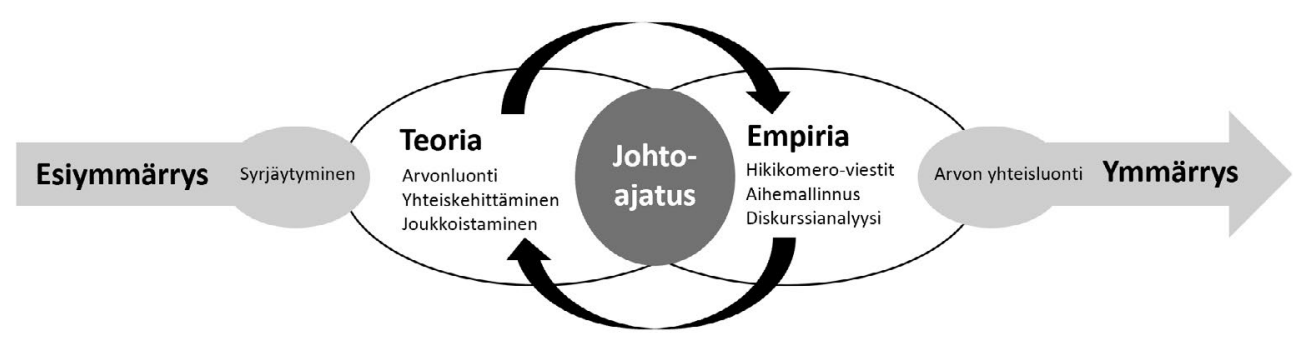

Kuvio 1. Abduktiivisen päättelyn logiikka ja tutkimusprosessin kuvaus.

ten arkeen. Nuorten verkkoyhteisöt voidaan nähdä myös yhteiskehittämisen kannalta hyödylliseksi resurssiksi. Kokemukset passiivisesta joukkoistamisesta (passive crowdsourcing, esim. Charalabidis ym. 2014) puhuvat sen puolesta, että yhteiskehittämistä voidaan tukea myös epätyypillisin tavoin. Passiivinen joukkoistaminen tarkoittaa sosiaalisen median alustoilla, blogeissa ja keskustelufoorumeilla julkaistujen sisältöjen hyödyntämistä. Joukkoistamista kutsutaan passiiviseksi, koska sen avulla voidaan ottaa systemaattisesta puheeksi asioita, joita ei ole ehdotettu 'palvelusysteemin' pyynnöstä, mutta jotka voivat kuitenkin paljastaa todellisuudesta ja kansalaisten arjesta puolia, jotka vaikuttavat palveluiden kehittämiseen ja tuottamiseen. Passiivinen joukkoistaminen on keino toteuttaa voimavaraperustaista yhteiskehittämistä, sillä sen ytimessä on 'äänen' antaminen heille, joita ei juuri kuulla työpajoissa, seminaareissa ja muilla yhteiskehittämisen tavanomaisilla foorumeilla.

\section{TUTKIMUKSEN TOTEUTTAMINEN}

Abduktiivisen päättelyn logiikkaa (Toivonen 1999, 46-47) hyödyntäen tutkimuksen johtoajatus - sosiaalisessa mediassa viestitellään asioista tavalla, jota voidaan hyödyntää palvelujen yhteiskehittämisessä - muodostettiin eksploratiivisen Hikikomero-aineistoon tutustumisen yhteydessä. Arvonluonnin, yhteiskehittämisen ja joukkoistamisen pohjalta hahmoteltiin tulkinnallinen viitekehys, jonka oikeellisuutta arvioitiin empiirisen aineiston valossa (kuvio 1.)

Abduktiivista päättelylogiikkaa noudattavaa tutkimusta voidaan pitää vuorovaikutteisena prosessina, jossa teoria ja empiria keskustelevat keskenään ja lisäävät ymmärrystä kohdeilmiös- tä. Aineistolähtöistä diskurssianalyysiä tuettiin tutkijaryhmän kokemuksilla sosiaalisen median hyödyntämisestä erilaisissa osallisuutta edistävissä tutkimus- ja kehittämishankkeissa.

Tutkimusaineisto koostui ylilauta.org-keskustelufoorumin Hikikomero-ryhmän keskusteluryhmään vuosina 2018 ja 2019 lähetetyistä viesteistä (https://ylilauta.org/hikky/). Ylilauta.org on anonyymi ja käyttäjien yksityisyyttä kunnioittava keskustelufoorumi, jossa ei juurikaan rajata keskustelunaiheita. Sivustolla on päivittäin kymmeniätuhansia käyttäjiä. Sivusto jakautuu kymmeniin teemoittain jäsentyneisiin ryhmiin. Hikikomero on yksi ryhmä, jonka ylläpitäjä määrittelee "masentuneiden ja sosiaalisesti syrjäytyneiden vertaistukiryhmäksi". Ryhmä on tarkoitettu ihmisille, jotka kokevat arkiset sosiaalisen kanssakäymisen muodot vaikeiksi ja itselleen sopimattomiksi. Oletettavaa on, että Hikikomerossa mielipiteitään ilmaisevia nuoria ei näy seminaareissa, kansalaisraadeissa ja työpajoissa. Näin on, koska hikikomori on määritelmällisesti sosiaaliseen vetäytymiseen pyrkivä henkilö (esim. Furlong 2008). Hikikomori tai 'hikkyt', kuten he itseään kutsuvat, voivat olla sosiaalisesti vetäytyneitä, mutta silti ahkeria verkkoviestijöistä. Sosiaalisesti vetäytyvien informaatiokäyttäytymisestä väitellyt Haasio (2015) on nimittäin havainnut, että sosiaalisesti vetäytyvät arvostavat vertaistukea. Käsillä olevan tutkimuksen näkökulmasta kiinnostavinta Haasion väitöksessä ovat kuitenkin teemat, joista Hikikomerossa keskustellaan, sillä suurin osa sivuston viesteistä käsittelee tavalla tai toisella hyvinvointia - tai pikemminkin kokemuksia sen puutteesta.

Tutkimuksen empiirisen aineiston analysointi koostui viidestä vaiheesta. Ensimmäisessä 
vaiheessa tutkijaryhmä hyödynsi Mohawk Analyticsin työkalua, ${ }^{1}$ jonka avulla ryhmä toteutti eksploratiivisen tutustumisen Hikikomerosivustolla julkaistuihin viesteihin. Operaatio osoitti, että kyse on vertaistukiryhmästä, jossa esiintyy melko paljon sote-järjestelmään kohdistuvaa keskustelua. Hikikomerossa ei arkailla mielipiteiden ja palvelukokemusten esittämistä keskeisistä sote-instituutioista. Valtaosa viesteistä osoittautui negatiivisesti värittyneeksi keskittyen erilaisiin ongelmiin, joihin hikikomerolaiset olivat törmänneet. Mohawk Analyticsin sivustolla ladattiin 76305 Hikikomerossa vuosina 2018-2019 julkaistua viestiä. Toisessa vaiheessa tutkijaryhmä hyödynsi Luuppi-nimistä digitaalista analysointityökalua, ${ }^{2}$ jonka avulla aineistosta etsittiin sote-instituutioita kuvaavia termejä (ml. slangi-ilmaisut). Toisen vaiheen hakutermeiksi valikoituivat 'Kansaneläkelaitos', 'Kela', 'nuorisojärjestö', 'nuorisotyö, 'sosiaalitoimisto', 'sossu', 'TE-toimisto', 'työvoimatoimisto', 'työkkäri', 'Diakonissalaitos' ja 'Vamos'. Kolmannessa vaiheessa hyödynnettiin ohjaamattoman koneoppimisen menetelmiin (ShalewShwartz \& Ben-David 2014) luokiteltavaa aihemallinnusta (Blei ym. 2003, Toivanen ym. 2020). Teimme näin, koska aihemallinnuksen avulla voidaan ryhmitellä tekstiä ja "löytää sieltä piilossa olevia rakenteita tai aiheita" (Nelimarkka 2020,9). Aihemallinnuksessa aineiston perusyksikköjä ovat dokumentit (po. tutkimuksessa Hikikomero-viestit) ja sanat. Aihemallinnuksen oletuksena on, että jokainen dokumentti on eräänlainen aiheinen yhdistelmä ja että jokaisella sanalla on tietty todennäköisyys kuulua jokaiseen aiheeseen (Puschmann ym. 2016, Toivanen ym. 2020). Alkuperäisestä 76305 viestiä sisältävästä aineistosta tunnistettiin aihemallinnuksen avulla kaikkiaan 3106 tutkimustehtävän kannalta relevanttia viestiä. Neljännessä vaiheessa viestit analysoitiin tehtävää varten rakennetun sanakirjan avulla. ${ }^{3}$ Tutkimustehtävän mukaisesti olimme kiinnostuneita erityisesti viesteistä, joissa kerrottiin sote-palveluihin liittyvistä ongelmista. Erotimme koneoppivan algoritmin avulla kaikista viesteistä negatiivisesti latautuneet viestit, joita oli kaikkiaan 1534 kappaletta. Tämän jälkeen analysoimme algoritmin avulla viesteissä esiintyvät diskurssit ja diskurssien tunnelataukset sekä koko aineistosta (3106 viestiä) että negatiivisista viesteistä. Yksi diskurssianalyysin teoreettisista lähtökohdista on oletus kielenkäytön sosiaalista todellisuutta rakentavasta luonteesta. Käyttäessämme kieltä me luomme merkityksiä - konstruoimme kohteet, joista puhumme tai kirjoitamme (Jokinen ym 2016). Sosiaalisen todellisuuden ja verkkoaineiston diskurssien välisen suhteen tunnistaminen ja tunnustaminen on edellytys sille, että verkkokeskusteluja voidaan ajatella hyödynnettävän palvelujen yhteiskehittämisessä. Diskurssianalyysissä voidaan kontekstin näkökulmasta ottaa huomioon näkymätön yleisö, jolle puhuja argumentoi varautuen jo etukäteen mahdollisiin vasta-argumentteihin (Jokinen ym 2016). Aineistosta tunnistamamme diskurssit edustavat erilaisia puhetapoja, joiden avulla viestien lähettäjät ilmaisevat kokemuksiaan ja suhtautumistaan keskeisiin sote-instituutioihin. Tunnistettujen diskurssien määrä perustuu algoritmin määrittämiin tunnuslukuihin, jotka mukailevat säästäväisyyden (parsimonious) periaatetta, jossa analysoitavaksi tulee mahdollisimman vähän eri teemoja, jotta niiden käsittely on tehokasta, mutta kuitenkin tarpeeksi monta, jotta niiden analysointi on tilastollisesti mielekästä. Selvimmät tulokset ilmenivät koko aineiston osalta neljässä diskurssissa ja negatiivisten viestien osalta kolmessa diskurssissa (ks. seuraava luku). Algoritmi analysoi diskurssit latentin Dirichlet-allokaation (LDA) avulla käyttäen Gibbsin otanta-algoritmia (Griffiths 2002). Diskurssien erot olivat tilastollisesti merkitseviä (sig. $<0.01$ ). Lopuksi teimme sentimenttianalyysin (sentiment analysis, ks. Helo \& Jalonen 2018) negatiivisten viestien osalta. Diskurssit erosivat negatiivisissa viesteissä tilastollisesti merkitsevästi (sig. <0.01) toisistaan odotuksen, pelon, surun ja luottamuksen osalta. Viidennessä vaiheessa koostimme aihemallinnuksen pohjalta diskurssianalyyttisen tulkinnan puhetavoista, joilla Hikikomerossa viestittelevät nuoret ilmaisivat omaa sosiaalista vetäytymistään ja näkemyksiään keskeisistä sote-instituutioista.

\section{TUTKIMUKSEN EMPIIRISET TULOKSET}

Verkon keskusteluryhmissä tieto rakentuu yhteisöllisesti vuorovaikutuksessa muiden käyttäjien kanssa (Haasio 2015). Hikikomero-aineiston kohdalla vuorovaikutuksessa korostuu kontekstisidonnaisuus. Hikikomeron omalakinen kie- 


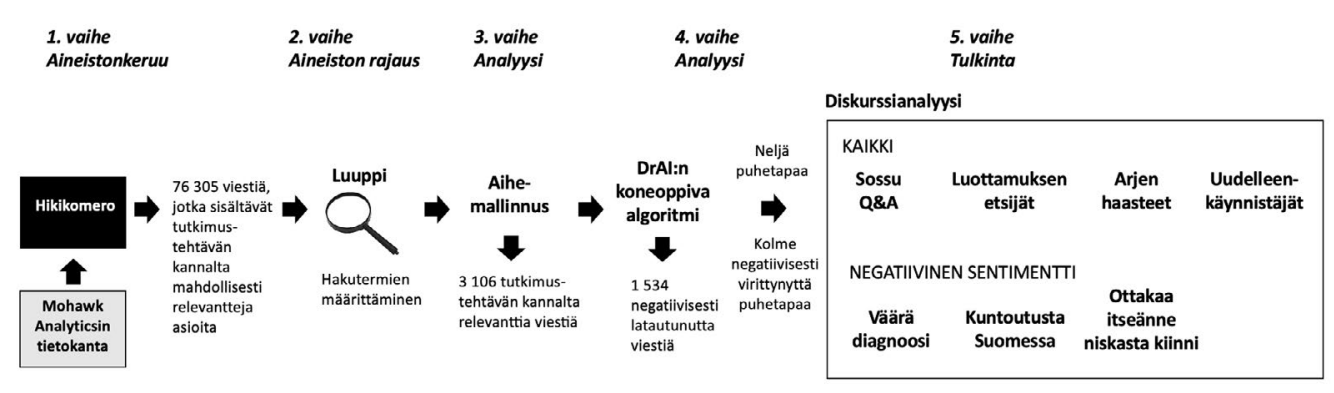

Kuvio 2. Aineiston keruu, rajaus, analysointi ja tulkinta.

lenkäytön rekisteri luo vastavoiman hymistelevälle huolipuheelle. Aineistossamme oletetut vasta-argumentit pääsääntöisesti joko sivuutetaan tai revitään verbaalisesti riekaleiksi. Yhteistä aineistossa käytettäville kielenkäytön rekistereille on verkon alakulttuureille tyypillinen anarkistisuus ja sisäänpäinlämpiävyys. Kaikissa aineistosta tunnistetuissa diskursseissa hyödynnetään vastajulkisuudelle ominaiseen tapaan valtajulkisuuden affektiivista ja kokemusperäistä haastamista (vrt. Dahlgren \& Alvares 2013, 50-51).

Aineistossa elävät diskurssit ja tunteet eivät useinkaan esiinny selkeinä kokonaisuuksina. Ylipäätään diskurssianalyysiin soveltuu heikosti selvärajaisten alkuhypoteesien rakentaminen. Suominen $(2016,53)$ toteaakin, että "aineistossa havaituista säännönmukaisuuksista on luontevaa nostaa hypoteeseja tutkimusprosessin aikana tarkemman analysoinnin aiheeksi." Otamme seuraavaksi tarkasteluun algoritmin avulla aineistosta erottuneet olennaisimmat teemat ja niiden pohjalta hahmotellut diskurssit. Aihemallinnuksen pohjalta koko aineiston tasolla neljäksi keskeiseksi diskurssiksi muodostuivat "Sossu Q\&A", "Luottamuksen etsijät", "Arjen haasteet" ja "Uudelleenkäynnistyjät". Esitämme kunkin diskurssin tarkastelun yhteydessä yhden edustavaksi arvioimamme autenttisen viestin. Viestit ovat anonyymejä, joten emme riko niiden esittämisellä Markhamin ja Buchananin (2012) "älä aiheuta pahaa" -periaatetta. (Ks. yhteenveto empiirisen aineiston analyysiprosessista ja tuloksista kuvio 2.)

"Sossu Q\&A"-diskurssissa korostuu vertaistuki erilaisten tukien hakemisessa. Vaikka diskurssi on nimetty siten, että se viittaa eksplisiittisesti sosiaalivirastoon/-palveluihin, niin tässä puhetavassa sossu on synonyymi kaikille palveluille ja tuille, joihin keskustelijat ovat mahdollisesti oikeutettuja. Suurin osa tästä keskustelusta koskee Kelaa. Yksittäisten viestien tasolla keskustelijat ovat suurilta osin hyvin tietoisia siitä, mistä palvelujärjestelmän haarasta tukea kannattaisi hakea. Toki myös avoimia kysymyksiä on paljon. Sentimentiltään keskustelu on pääsääntöisesti positiivista. Keskustelijat jakavat ja vastaanottavat vinkkejä sekä spekuloivat mahdollisuuksillaan. Diskurssiin liittyy myös vahvasti eräänlainen Robin Hood -mentaliteetti. Rikkailta köyhille -puhetapa on usein väkevästi läsnä, eikä huumorikaan loista poissaolollaan.

"Kela Gold on vähän huono nimitys. Itse kehittelin taulukon, jos Kelan maksamat tuet olisivat nimetty kuin luottokortit.

Kela Basic Gold (KBG) (pelkkä toimeentulotuki)

Kela Basic Gold++ (KBG++) (työmarkkinatuki, tt-tuki ja asumistuki)

Kela Public Labor Gold (KPLG) (työmarkkinatuki, tt-tuki, asumistuki, matkakorvaus, kulukorvaus)

...

Kela Limited Time Platinum Executive (KLTPE) (kuntoutustuki, eläkkeensaajan asumistuki, takuueläke)

Kela Diamond Executive Premium Platinum Superior Black (KDEPPSP) (kansaneläke, eläkkeensaajan asumistuki, takuueläke)"

"Luottamuksen etsijät" -diskurssissa nousevat esiin huolet toimeentulosta, asumisesta ja avun 
hakemisesta vanhemmilta. Tähän kategoriaan luokitellut viestit välittävät hoivan ja välittämisen tarvetta. Arjesta ja sairaanhoidollisista kuluista selviäminen huolettaa. Diskurssissa korostuvat vihan, pelon, inhon, ilon, surullisuuden ja luottamuksen tunteet.

"Omat vanhemmat lopetti kyselemisen joskus parin kympin jälkeen. Muut sukulaiset kyselee edelleen, vaikka ikää 35 . Jokunen vuosi sitten lopetin valehtelun ja selittelyn kaikille. Eli olen sanonut suoraan, että elän kelan tuilla ja makailen lähinnä kotona. Tavallaan helpottavaa ja vapauttavaa, kun ei tarvitse kulisseja yrittää pitää pystyssä. Aika erilaisia reaktioita on tullut. Osa sanoo, että se on vain semmoinen vaihe elämässä. Toiset voivottelee ja kolmannet sitten pitää ihan lusmuna. Tavallaan kaikki ovat oikeassa, mutta eipä kukaan tiedä, että millaisen paskan ja traumojen jälkeen tähän tilanteeseen olen ajautunut."

"Arjen haasteet" -diskurssissa korostuu palvelujärjestelmän keskeinen rooli. Tukijärjestelmien toimivuus koetaan elämän ja kuoleman kysymykseksi. Mikäli järjestelmä tarjoaa selkänojaa, niin elämän edellytykset ovat olemassa. Toisaalta tukien leikkaaminen voi aiheuttaa romahduksen, ainakin yksittäisen viestin tekstin tasolla. Luottamus on keskeinen tunne, niin hyvässä kuin pahassa.

"Napsahti kielteinen kuntoutustukipäätös. Perusteluina se perus että emme koe että oot tarpeeks sairas. B-lausunto oli mielestäni järkyttävän paska, siinä ei edes kuvailtu oireitani vaan kerrottiin muun muassa milloin olen ollut sairaalassa osastolla? Liitteenä oli kyllä toimintaterapeutin ja psykologin lausunnot mutta mahtaako niillä olla edes merkitystä tai lukeeko kelan tantat niitä? Ens viikolla on lääkäri, pyydän uutta lausuntoa ja jos samanlainen paska tulee niin onko lääkärin vaihtaminen miten iso prosessi. Ainakin menee hankalaksi kun taas pitää tutustua uuteen ihmiseen joka ei tiedä musta mitään. Jee.”

"Uudelleenkäynnistyjät"-diskurssissa on mukana odotuksen tunne. Yksi keskeinen teema on työllistyminen. Miten voin työllistyä? Mistä löytää töitä? Mistä saada apua uuteen alkuun?
Tulevaisuus ei ole tässä puhetavassa vain tasaista harmaata tai taistelua järjestelmää vastaan, vaan mahdollisuus 'normoutumiseen' on olemassa. ${ }^{4}$

"Itse sain onnekseni kelalta tuen psykoterapiaan. Se on ollut minulle iso apu. Se on jännää miten näin aikuisena edelleen on kiinni jossain lapsen lojaaliudessa vanhempia kohtaan, olivat he millaisia tahansa. Terapeutti hiljattain eräässä istunnossa kutsui isäni toimia sadistisiksi, kun kuvailin lapsuusen kokemuksia. Heti kun joku toinen sanoi niin, asiat saivat ihan eri painon. Sisälläni nousi tarve vähätellä tekojen raskautta mutta samaan aikaan katsoin isän tekoja aikuisena ja olin terapeutin kanssa samaa mieltä. Pari päivää sen jälkeen olin henkisesti aivan finaalissa mutta nyt tuntuu keveämmältä. Pitkin elämää olen ruoskinut itseäni siitä että olen niin saamaton luuseri. Nyt on hiljalleen alkanut kehittymään empatiaa itseäni kohtaan.”

Kun tarkastellaan negatiivisesti latautuneita viestejä, niin aineistosta nousee esiin vielä kolme tarkemmin rajattavaa diskussia: "Kuntoutusta Suomessa", "Ottakaa itseänne niskasta kiinni" ja "Väärä diagnoosi". Sentimentiltään negatiiviset viestit ovat usein keskiössä, kun pohditaan, miten erilaisia palveluja voitaisiin kehittää. Aineiston perusteella jo koko viestimäärästä voi tunnistaa palvelujärjestelmän kipupisteitä, mutta negatiivisten viestien tarkastelu antaa lisää syvyyttä analyysiin. Esimerkiksi "Väärä diagnoosi"-diskurssissa yksiä keskeisimpiä pintaan nousevia tunteita ovat pelko ja luottamus. Epäluottamus palvelujärjestelmää kohtaan on vahva, sillä luottoa oikeudenmukaisiin päätöksiin ei löydy. Byrokratian loukkuihin juuttuminen on aina läsnä.

"Kuusihenkinen perhe pärjäsi kohtalaisen hyvin niin kauan, kun sai Kelalta sairauspäivärahaa. Kun se [...] loppui, mies haki työkyvyttömyyseläkettä. Hakemuksen käsittelyssä kesti monta kuukautta. Lopulta päätös tuli. Se oli kielteinen. "Arvioimme, että sairautenne vuoksi työkykynne on alentunut raskaaseen työhön. Teillä on kuitenkin työkykyä jäljellä fyysisesti vähän kuormittavaan työhön, jolla voitte ansaita kohtuullisen toimeentulona", Kelan päätöksessä luki. Sinällään ymmärrän 
miksi tuossa ei myönnetä kuntoutustukea. Kumminkin pää toimii ja kykenisi esim. Tietokone hommiin mikäli käsi sen verran toimii ja muuten normo kunnossa. Tätä juuri miettinyt kun henkisillä sairauksilla näyttäisi pääsevän Tke:lle helpommin, kuin fyysisillä. Toisaalta ymmärrettävää jos nuppi ei toimi ja on itsemurha ajatukset mielessä ei siinä töihin kykene. Muutenkin henkiset sairaudet voivat oireilla myös fyysisesti."

Pelko on olennaisin tunne "Kuntoutusta Suomessa"- ja "Ottakaa itseänne niskasta kiinni" -diskursseissa. Jälkimmäisen suhteen tunteista myös viha nousee korostuneesti esiin. Tässä diskurssissa elää vahvasti "olen oman elämäni herra” -mentaliteetti. Valittajat nähdään heikkoina sortujina, ja itse tehty päätös elää tukien varassa on rationaalisen päättelyketjun lopputulos. Suomalaista hyvinvointiyhteiskuntaa ruoditaan rankimmin "Kuntoutusta Suomessa" -diskurssiin luettavissa viesteissä. Suomen palvelujärjestelmän kykyä tukea heikoimmassa asemassa olevia ei pidetä kovin suuressa arvossa.

"Ihan turha antaa tuolle vauvalle mitään vääriä toivoja. Ellei hän päädy opiskelemaan jotain vaikeaa varman työllisyyden alaa kuten lääketiedettä niin pätkätöiden, työttömyyden, kela-byrokratian ja paskan arjen täyttämä elämä on taattua. Ei ole todellakaan lottovoitto syntyä Suomeen jos on köyhästä perheestä. Subjektiivinen köyhyys on jopa pahempaa kuin se ettei esim. ole sähköjä jossain favelassa. Ja jäät käytännössä kotisi vangiksi kun ei ole varaa tehdä yhtään mitään tai tehdä yhtään mitään, eikä sinua palkata mihinkään vaikka hakisit satoja paikkoja. Eli olet silloin elävässä helvetissä jumissa, jopa vuosia tai vuosikymmeniä. Ainoa asia mikä estää näitä ihmisiä sekoamasta totaalisesti tai tekemästä väkivaltaa on se että heillä on edes se katto pään päällä. Ilman sosiaaliturvaa tämä maa ei eroaisi jostain Kolumbiasta millään tavoin ja täällä ammuttaisiin ihmisiä kaduille päivittäin, katuryöstöjä tapahtuisi 30 minuutin välein jne."

Ylilaudan Hikikomerossa elävät palvelujärjestelmään linkittyvät diskurssit tuovat rosoisia ääniä syrjäytyneiden nuorien auttamista koskevaan keskusteluun. Hyvinvointiyhteiskunnan instituutiot eivät saa kovin hellävaraista käsittelyä, vaan keskiössä ovat palvelujärjestelmän hyväksikäyttö, aidon kohtaamisen vaikeus, luottamuksen puute, jokapäiväisestä elämästä selviäminen ja toivon etsiminen. Toisaalta monet viesteistä ovat sävyltään positiivisia. Parempaa huomista kaivataan ja järjestelmän tarjoamiin palveluihin ollaan tyytyväisiä - kunhan niitä voidaan hyödyntää omilla ehdoilla.

Hikikomero-keskustelualue on kuitenkin lopulta vain pieni kurkistus syrjäytyneiden puhetapoihin, joten pitkälle meneviä johtopäätöksiä ei tämän analyysin perusteella voi tehdä. Ja kun kyseessä on avoin anonyymi keskustelupalsta, niin mitään takeita ei ole siitä, että viestien kirjoittajat ovat ylipäätään syrjäytyneitä nuoria. Aineisto antaa silti pienen kurkistuksen siihen maailmaan, joka palveluiden kehittämisessä jää yleensä vähälle huomiolle.

\section{YHTEENVETO JA POHDINTA}

Suomalaisessa keskustelussa syrjäytyminen mielletään usein ihmisen omien toimien - tai tarkemmin toimimattomuuden - seuraukseksi. Aktivoinnin retoriikkaan viitaten esimerkiksi Pohjola $(2001,189)$ on todennut sarkastisesti, että "suomalainen on niin aktiivinen, että hän syrjäytyykin itse". Yhteiskuntaan kiinnittymistä on Suomessa pidetty "moraalisen imperatiivina" ja syrjäytyminen nähty "osoitukseksi integraatiovajeesta" (Helne 2000, 189). Huolipuhe on ymmärrettävää, mutta samalla itsessään ongelmallista, sillä sen seurauksena syntyy helposti yksisuuntaisia yleistyksiä, jotka määrittävät nuoret "erilaisten aktivoivien ja uudelleen sosiaalistavien toimintapoliitikkojen kohteiksi" (Pohjola 2001, 189). Yhteiskunnallisiin instituutioihin kiinnittymisen puute koetaan helposti uhkaksi ja vastatoimenpiteitä edellyttäväksi. Harvemmin pohditaan sitä vaihtoehtoa, että valtakulttuurin ulkopuolisen elämäntavan valinneet nuoret olisivatkin jotakin muuta kuin syrjäytyneitä sanan varsinaisessa merkityksessä (esim. Komonen 2013).

Palvelujen saatavuutta arvioivat some-keskustelut - kärjekkäätkin sellaiset - voidaan ymmärtää asiakaspalautteeksi, joka auttaa tunnistamaan palvelusysteemin pullonkauloja. Ongelmien tunnistamisesta toiminnan muuttamiseen 
on kuitenkin pitkä matka. Yhden merkittävimmistä syistä muodostavat sote-organisaatioiden kulttuuriset piirteet, joina on yleisesti pidetty vahvaa professionaalisuutta, hierarkkista rakennetta ja toiminnan normatiivisuutta. Kulttuuristen muutosten aikaansaaminen on aina vaikeaa, mutta sote-organisaatioissa se saattaa olla erityisen hidasta (Kinnunen 2017). Professionaalisuus, hierarkkisuus ja normatiivisuus tuottavat tehokasta tiedonkulkua hallinnonalojen sisällä, mutta muodostuvat ongelmallisiksi, kun tehtävänä on rakentaa palveluja, jotka edellyttävät moniammatillista yhteistyötä. Haasteeksi muodostuu yhtäältä riittävän monipuolisen tiedon kerääminen ja toisaalta kerätyn tiedon hyödyntäminen yli hallinnonalarajojen. Esimerkiksi Kosklin ym. $(2020,86)$ muistuttavat, että "asiakaspalautetiedon hyödyntäminen edellyttää yhteistä keskustelua koko tiedonhallinnan prosessista, sopimisista yhtenäisistä toimintatavoista ja toimivien johtamiskäytäntöjen kehittämistä". Verbaalisesti lennokkaat arjen kokemukset jäävät helposti yksittäisiksi tiedonmurusiksi. Näin käy erityisesti silloin, jos palvelujen kehittämistä ohjaava tietokulttuuri rakentuu avoimuuden ja luottamuksen sijaan kontrollille ja moitteen välttämiselle (ks. Vakkala \& Syväjärvi 2020).

Asiakaspalautteen lisäksi palveluiden saatavuutta ja laatua arvioivat some-keskustelut voidaan nähdä myös nuorten tarjoamana kokemustietona (expertise by experience). Kysymys on tiedosta, joka on syntynyt nuoren omista tai hänen lähipiirinsä kokemuksista (ks. esim. Bäcklund 2007). Ideaalitilanteessa nuorten kertomukset esimerkiksi työllistymisen vaikeuksista voisivat tarjota kunnan työllistymispalveluista vastaaville 'silminnäkijähavaintoja' palveluiden koetuista puutteista tavalla, joita on vaikea saada muilla keinoin. Ideaalin toteutumisen esteenä on usein kuitenkin se, että kunnissa ei olla valmiita avaamaan prosesseja palveluiden suunnitteluvaiheessa. Yhteiskehittämisestä puhutaan, mutta kovin usein kuntalaisilta pyydetään palautetta vasta valmiista vaihtoehdoista tai olemassa olevista palveluista (Jurmu 2020, 168). Palautetieto on hyödyllistä, mutta aidosta yhteiskehittämisestä voidaan puhua vasta silloin, kun palvelujen käyttäjien kokemukset ja näkemykset ohjaavat myös palvelujen suunnittelua.

Vaikeita elämänkokemuksia läpikäyneet nuoret ovat oman elämänsä asiantuntijoita, joiden asiantuntijuus ei kuitenkaan itsestään välity osaksi yhteiskehittämisen tietoperustaa (ks. Meriluoto 2018). Artikkelin yhtenä kontribuutiona onkin ymmärryksen lisääminen digitaalisten aineiston hyödyntämisestä osana yhteiskehittämistä tilanteissa, joissa yksi kehittäjäryhmä suhtautuu penseästi osallistumisen perinteisiin muotoihin. Empiirisen aineiston pohjalta muodostetut neljä diskurssia havainnollistavat valtakulttuurin ulkopuolella elävien nuorten suhtautumista sote-palvelujärjestelmän keskeisiin instituutioihin. Samalla ne antavat arvokasta informaatiota järjestelmässä koetuista pullonkauloista. Tätä tietoa voidaan hyödyntää palveluiden hienosäätämisen lisäksi esimerkiksi julkishallinnon viestinnässä. Hikikomeron avaama kuva yhteiskunnallisista instituutioista syrjässä olevien nuorten maailmaan tarjoaa uusia mahdollisuuksia myös lakisääteisessä Valtakunnallinen nuorisotyön ja -politiikan ohjelmassa (OKM 2020) asetettujen tavoitteiden saavuttamiseen, sillä myös hikkyiksi itseään kutsuvat nuoret haluavat sujuvaa arkea ja kokea merkityksellisyyden tunnetta. Palvelujärjestelmä tekee itselleen palveluksen kuuntelemalla myös niitä nuoria, jotka eivät osallistu työpajoihin ja seminaareihin. Vaikka hikky-diskurssien hyödyntämisessä ei olekaan kysymys puntaroivaan demokratiakäsitykseen (esim. Raisio ym. 2014, Chambers 2018) perustuvasta toiminnasta, diskurssien tunnistaminen edistää arvon yhteisluontia, sillä aidossa arvon yhteisluonnissa palvelun loppukäyttäjällä on sananvaltaa kehitettävän palvelun sisältöön, laatuun ja saatavuuteen. Yhteiskehittämisen näkökulmasta diskurssit voidaan ymmärtää palvelujen loppukäyttäjien kuvauksiksi palvelutarpeista ja palveluihin kohdistuvista odotuksista (kuvio 3). Optimistisesti voidaankin ajatella, että some-aineistojen hyödyntäminen tarjoaa mahdollisuuden korjata yhteiskehittämisessä tunnistettua aktiivisten ja hyväosaisten kansalaisten etuja palvelevaa vinoumaa. Voimavaralähtöisen yhteiskehittämisen hengessä kysymys on viime kädessä siitä, että syrjäytyneet nuoret nähdään subjekteina objektien sijaan. Myös vaikeissa olosuhteissa elävät nuoret etsivät elämäänsä merkityksellisyyttä. Ajatuksen muuttaminen toiminnaksi puolestaan edellyttää, että palvelujen kehittämisestä vastaavat tahot aidosti motivoituvat osallistumisten kynnysten madaltamisesta.

Syrjäytyneiden nuorten ottaminen mukaan 


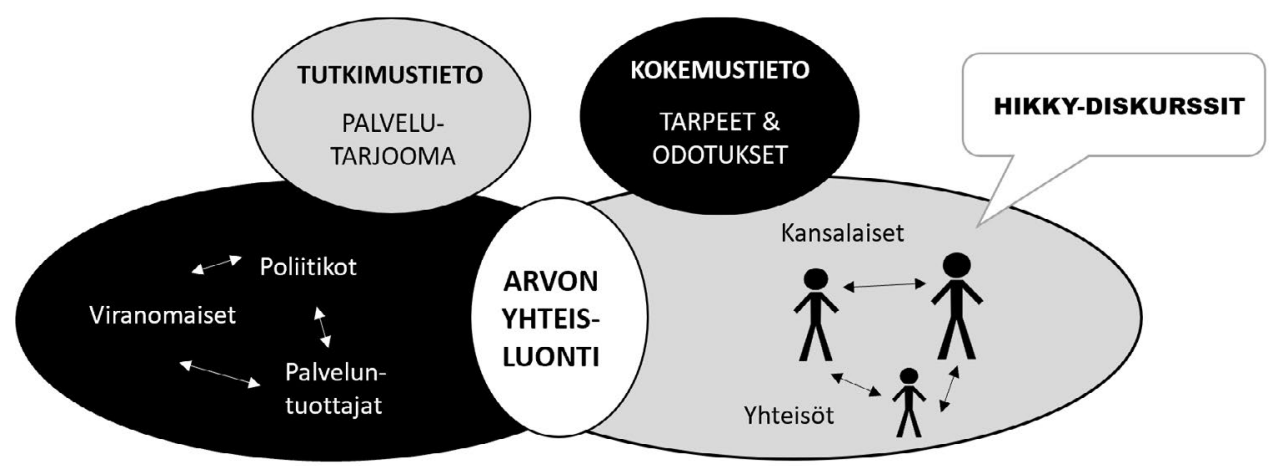

Kuvio 3. Hikky-diskurssien rooli arvon yhteisluonnissa.

palvelujen yhteiskehittämiseen on paljolti viranhaltijoiden innovatiivisuuden varassa. Lainsäädäntö asettaa reunaehdot some-keskustelujen hyödyntämiselle, mutta ei estä artikkelissa kuvattua menetelmää. Teknologia kehittyy vauhdilla ja oletettavaa onkin, että jo lähivuosina some-keskustelujen analysointi onnistuu tekoälyn avulla. Ohjaamattoman koneoppimisen hyödyntäminen hikky-diskurssien tunnistamisessa on johdonmukainen niiden pyrkimysten kanssa, joissa peräänkuulutetaan tekoälyn nykyistä laajamittaisempaa hyödyntämistä julkisella sektorilla (esim. OECD 2019, valtioneuvoston kanslia 2019, Autioniemi 2020). Artikkelissa on osoitettu, että ohjatun ja ohjaamattoman koneoppimisen avulla voidaan nopeuttaa isojen aineiston haltuunottoa ja kokonaiskuvan muodostamista sekä aineiston mielekästä rajaamista ajallisesti ja teemallisesti. Oppivien algoritmien avulla hallinnolle tarjoutuu mahdollisuus tunnistaa ja merkityksellistää syrjäytymisvaarassa olevia nuoria askarruttavia puheenaiheita. Diskurssien ja algoritmien yhdistelmä auttaa rakentamaan ennakoivaa ja vuorovaikutteista viestintää hallinnon ja kansalaisyhteisyhteiskunnan välille tavalla, joka palvelee myös osallisuuden tarpeita (ks. esim. Merikukka ym. 2019, Pernaa 2020).

Some-keskustelujen hyödyntäminen palvelujen yhteiskehittämisessä on linjassa myös OECD:n alaisen julkista innovointia edistävän OPSIn (Office of Public Sector Innovation) politiikkasuositusten kanssa, joissa korostetaan muun muassa hallinnon ja kansalaisten välistä dialogia sekä aktiivista kansalaispalautteen keräämistä (OECD 2017). Choon (2013) tietokult- tuurin pääulottuvuuksia mukaillen kyse on sisäisesti suuntautuneen tiedon etsinnän sekä kontrollia ja yhtenäisyyttä korostavan sääntöjä noudattavan tietokulttuurin korvaamisesta riskejä ottavalla tietokulttuurilla, jossa kannustetaan innovaatioihin, luovuuteen ja uusien ideoiden kokeiluun (Vakkala \& Syväjärvi 2020, 125).

Tutkimuksen rajaaminen Hikikomero-viesteihin on tutkimustehtävän kannalta mielekäs ratkaisu, mutta samalla valinta, joka heikentää tulosten hyödynnettävyyttä palvelujen yhteiskehittämisessä. Pääosin anonyymit ja ilmaisultaan hyökkäävät viestit sisältävät paljon pahanolonpurkauksia. Tutkimuksessa on havaittu, että vastajulkisuuden harrastaminen on tyypillisintä anonyymeillä keskustelufoorumeilla (ks. Vainikka \& Harju 2019). Syyttämisen logiikka ja perusteet jäävät niissä usein epämääräisiksi, mikä tekee korjaavien toimenpiteiden suunnittelun vaikeaksi. Yhtenä jatkotutkimusaiheena esitetäänkin tässä tutkimuksessa muodostetun puhetapatypologisoinnin testaamista toisenlaisissa sosiaalisen median ympäristöissä, kuten vaikkapa Kansaneläkelaitoksen Facebook-sivuilla.

Ehkä merkittävin jatkotutkimusaihe liittyy kuitenkin syrjäytymisvaarassa olevien nuorten äänen integrointiin osaksi palvelujen yhteiskehittämistä. Puhetapojen tunnistamisesta on paljon matkaa siihen, että nuorten ääni myös näkyy palvelujen suunnittelussa ja tuotannossa. Tämä edellyttää nähdäksemme toimintaorientoituneita tapaustutkimuksia, joissa pyritään kehittämään kohteena olevia julkisorganisaatioita niiden toimintatapoihin vaikuttamisen kautta. 


\section{VIITTEET}

1 https://www.mohawkanalytics.com/

2 Luuppi-työkalu on kehitetty Business Finlandin rahoittamassa DEEVA-hankkeessa (2016-2019) ja Horisontti2020-ohjelmasta rahoitetussa CoSIE-hankkeessa (2017-2020). Työkalu koostuu hakurobotista, opetuskäyttöliittymästä, viestien käsittelymenetelmästä ja visualisointityökalusta.

3 Hyödynsimme aihemallinnuksessa ja analyysissä DrAI:n (http://drai.fi/) tekoälyyn perustuvaa algoritmia. Ks. liite 1.

4 Hikikomeron rekisterissä normoutumisella tarkoitetaan paluuta tai siirtymää ns. normaaliin elämään. Normo juontuu termistä 'normihomo' eli normaali ihminen.

\section{LÄHTEET}

Autioniemi, Jari (2020). Tekoälyn yhteiskehittäminen julkisella sektorilla. Hallinnon Tutkimus, 39(1), 5-20. https://doi.org/10.37450/ht.98075

Baron, Samatha \& Stanley, Tony \& Colombian, Carmen \& Pereira, Tricia (2019). Strengthsbased Approach: Practice Framework and Practice Handbook. DHSC, London.

Bauman, Zygmunt (2000). Liquid Modernity. Polity Press, Cambridge.

Blei, David \& Bg, Andrew \& Jordan, Michael (2003). Latent Dirichlet allocation. Journal of Machine Learning Research, 3(4-5), 993-1022. DOI: 10.1162/jmlr.2003.3.4-5.993

Bovaird, Tony (2007). Beyond engagement and participation: user and community coproduction of public services. Public Administration Review, 67(5), 846-860.

https://doi.org/10.1111/j.15406210.2007.00773.x

Bowker, Julian \& Rubin, Kenneth \& Coplan, Robert (2016). Social Withdrawal. Teoksessa Levesque, Roger, J. R. (toim.) Encyclopedia of Adolescence. Springer, Cham.

Boyd, Danah (2008). Taken Out of Context: American Teen Sociality in Networked Publics. University of California, Berkeley, CA.

Brandsen, Taco \& Honingh, Marlies (2018). Definitions of co-production and co-creation. Teoksessa Brandsen, Taco., Steen, Trui \& Verschuere, Bram (toim.) Co-production and Co-creation. Engaging Citizens in Public Services, 9-17. Routledge, London. https://doi.org/10.4324/9781315204956
Bäcklund, Pia (2007). Tietämisen politiikka. Kokemuksellinen tieto kunnan hallinnassa. Helsinki: Helsingin kaupungin tietokeskus.

Chambers, Simone (2018). The philosophic origins of deliberative ideals. Teoksessa Bächtiger, Andre \& Dryzek, John, S. \& Mansbridge, Jane \& Warren, Mark (toim.) The Oxford Handbook of Deliberative Democracy, 55-69. Oxford University Press, Oxford. https://doi.org/10.1093/oxford$\mathrm{hb} / 9780198747369.001 .0001$

Charalabidis, Yannis \& Loukis, Euripidis \& Androutsopoulou, Aggeliki \& Karkaletsis, Vangelis \& Trianfillou, Anna (2014). Passive crowdsourcing in government using social media. Transforming Government: People, Process and Policy, 8(2), 283-308. https://doi.org/10.1108/TG-09-2013-0035

Chatman, Elfreda, A. (1991). Life in a small world: Applicability of gratification theory to information-seeking behavior. Journal of the American Society for Information Science, 42(6), 438-449. https://doi.org/10.1002/(SICI)10974571(199107)42:6<438::AID-ASI6>3.0.CO;2-B

Choo, Chun Wei (2013). Information culture and organizational effectiveness. International Journal of Information Management, 33, 775-779. https://doi.org/10.1016/j.ijinfomgt.2013.05.009

Christofides, Emily \& Muise, Amy, \& Desmarais, Serge (2012). Risky disclosures on Facebook: The effect of having a bad experience on online behavior. Journal of Adolescent Research, 27(6), 714-731. https://doi.org/10.1177/0743558411432635

Davila. Joanne \& Stroud, Catherine, B. \& Starr, Lisa, R. (2009). Romantic and sexual activities, parent-adolescent stress, and depressive symptoms among early adolescent girls. Journal of Adolescence, 32(4), 909-924.

https://doi.org/10.1016/j.adolescence.2008.10.004

Dahlgren, Peter \& Alvares, Claudia (2013). Political participation in an age of mediatization. Javnost: The Public, 20(2), 47-65. https://doi.org/10.1080/13183222.2013.11009114

Dinishak, Janette (2016). The deficit view and its critics. Disabilities Studies Quarterly, 36(4). http://dx.doi.org/10.18061/dsq.v36i4.5236

Dunlop, Sally \& Freeman, Becky \& Jones, Sandra, C. (2015). Marketing to youth in the digital age: The promotion of unhealthy products and health promoting behaviours on social media. Media and Communication, 4(3), 35-49. http://dx.doi.org/10.17645/mac.v4i3.522

Emirbayer, Mustafa \& Mische, Ann (1998). What Is agency? American Journal of Sociology, 103(4), 
962-1023.

https://doi.org/10.1086/231294

Fox, Chris \& Jalonen, Harri \& Baines, Susan \& Bassi, Andrea \& Marsh, Caroline \& Moretti, Veronica \& Willoughby, Michael (2019). Co-creation of Public Service Innovation - Something Old, Something New, Something Borrowed, Something Tech - CoSIE White Paper. Reports from Turku University of Applied Sciences 259, Turku.

Frankl, Viktor, E. (1946). Man's Search for Meaning. New York: Washington Square Press.

Furlong, Andy (2008). The Japanese hikikomori phenomenon: acute social withdrawal among young people. The Sociological Review, 56(2), 309-325.

https://doi.org/10.1111/j.1467954X.2008.00790.x

Haasio, Ari (2015). Toiseus, tiedontarpeet ja tiedon jakaminen tietoverkon "pienessä maailmassa": Tutkimus sosiaalisesti vetäytyneiden henkilöiden informaatiokäyttäytymisestä. Acta Universitatis Tamperensis 2082, Tampere.

Hardyman, Wendy, Daunt, Kate \& Kitchner, Martin (2015). Value co-creation through patient engagement in healthcare. Public Management Review, 17(1), 90-107.

https://doi.org/10.1080/14719037.2014.881539

Helne, Tuula (2000). Toiseudesta yhteisyyteen - kysymyksiä syrjäytymiskeskustelun oletuksista. Teoksessa Heikkilä, Matti \& Karjalainen, Jouko (toim.). Köyhyys ja hyvinvointivaltion murros. Gaudeamus, Helsinki.

Helo, Tuomo \& Jalonen, Harri (2018). Tunnistaako kone tunteesi? Sävyanalyysi sosiaalisen median sisältöjen tulkinnassa. Teoksessa Isotalus, Pekka, Jussila, Jari. \& Matikainen, Janne (toim.) Twitter viestintänä - ilmiöt ja verkostot, 276295. Vastapaino, Tampere.

Griffiths, Tom (2002). Gibbs sampling in the generative model of Latent Dirichlet Allocation. Saatavilla:

http://www-psych.stanford.edu/ gruffydd/ cogsci02/lda.ps

Ilmakunnas, Ilari \& Kauppinen, Timo, M. \& Kestilä, Laura (2015) Sosioekonomisten syrjäytymisriskien kasautuminen vuonna 1977 syntyneillä nuorilla aikuisilla. Yhteiskuntapolitiikka, 80(3), 247-262.

Jalonen, Harri (2019a). Julkisten palvelujen yhteiskehittäminen - kaunista puhetta vai suomalaisen julkishallinnon arkea? Hallinnon Tutkimus, 38(4), 305-311.

Jalonen, Harri (2019b). The value of esports is in the eye of the beholder - but can esports operators influence what the spectators see?
Advances in Applied Sociology, 9(7), 306-329. https://doi.org/10.4236/aasoci.2019.97023

Jalonen, Harri \& Helander, Nina \& Mäkelä, Leena (toim.) (2020). Arvostustalous - kuinka arvostus rakentuu ja rakennetaan digiyhteiskunnassa. Vastapaino, Tampere.

Jelenchick, Lauren, A. \& Eickhoff, Jens C. \& Moreno, Megan, A. (2013). "Facebook depression?" Social networking site use and depression in older adolescents. Journal of Adolescent Health, 52, 128-130.

https://doi.org/10.1016/j.jado-

health.2012.05.008

Jokinen, Arja \& Juhila, Kirsi \& Suoninen, Eero (2016). Diskursiivinen maailma: Teoreettiset lähtökohdat ja analyyttiset käsitteet. Teoksessa Jokinen, Arja \& Juhila, Kirsi \& Suoninen, Eero (toim.) Diskurssianalyysi - Teoriat, peruskäsitteet ja käyttö. Vastapaino, Tampere.

Jordán-Conde, Zayira \& Mennecke, Brian \& Townsend, Anthony (2014). Late adolescent identity definition and intimate disclosure on Facebook. Computers in Human Behavior, 33, 356-366.

https://doi.org/10.1016/j.chb.2013.07.015

Jurmu, Liisa (2020). Miten kuntalaisten kokemustiedon hyödyntäminen nähdään kuntien uudistamisessa? Hallinnon Tutkimus, 39(3), 156-172.

Kato, Takahiro, A. \& Tateno, Masaru \& Shinfuku, Naotaka \& Fujisawa, Daisuke \& Teo, Alan, R. \& Sartorius, Norman \& Akiyma, Tsuyoshi \& Ishida, Tetsuya \& Choi Tae, Young \& Balhara, Yatan Pal Singh \& Matsumoto Ryohei \& Umene-Nakano, Wakako \& Fujimura, Yota \& Wand, Anne \& Chang, Jane Pei-Chen \& Chang, Rita Yuan-Feng \& Shadloo, Behrang \& Ahmed, Helal Uddin \& Lerthattasilp, Tiraya \& Kanba, Shigenobu (2012). Does the 'hikikomori' syndrome of social withdrawal exist outside Japan? A preliminary international investigation. Social Psychiatry and Psychiatric Epidemiology, 47(7), 1061-1075. https://doi.org/10.1007/s00127-011-0411-7

Keating, Avril \& Melis, Gabriella (2017). Social media and youth political engagement: Preaching to the converted or providing a new voice for youth? The British Journal of Politics and International Relations, 19(4), 877-894. https://doi.org/10.1177/1369148117718461

Kinnunen, Juha (2017). Organisaatiokulttuuri ja johtaminen. Teoksessa Rissanen, Sari \& Lammintakanen, Johanna (toim.) Sosiaali- ja terveysjohtaminen, 167-182. Sanoma Pro, Helsinki.

Komonen, Katja (2013). Mistä syrjäytymisessä on kysymys? Syrjäytyminen käsitteenä ja puhee- 
na. Teoksessa Ronkainen, Jussi \& Punamäki, Marika (toim.) Nuoret ja syrjäytyminen ItäSuomessa. Tutkimuksia ja raportteja 78, Mikkelin ammattikorkeakoulu, Mikkeli.

Kosklin, Ritva \& Lammintakanen, Johanna \& Kivinen, Tuula (2020). Asiakaspalautetieto ja sen hyödyntäminen sairaalan johtamisessa. Hallinnon Tutkimus, 39(2), 75-89. https://doi.org/10.37450/ht.98082

Kulmala, Anna 2004). Toiset identiteettiä rakentamassa. Yhteiskuntapolitiikka, 69(3), 231-241.

Kups, Sarah, Prinz, Christopher, Valfort, MarieAnne, Miranda Veerle, Queisser Monika \& Scarpetta Stefano (2019). Nuorten palvelut syynissä OECD:n arviointi nuorten palveluista Suomessa vuonna 2018. Opetus- ja kulttuuriministeriön julkaisuja 2019:18.

Kross, Ethan \& Verduyn, Philippe \& Demiralp, Emre \& Park, Jiyoung \& Lee Seungjae, David \& Lin, Natalie \& Shablack, Holly \& Jodines, John \& Ybarra, Oscar (2013). Facebook use predicts declines in subjective well-being in young adults. PLoS ONE, 8(8), 1-6. https://doi.org/10.1371/journal.pone.0069841

Markham, Annette \& Buchanan, Elizabeth (2012). Ethical Decision-Making and Internet Research: Recommendations from the AoIR Ethics Working Committee (Version 2.0).

Saatavilla: https://aoir.org/reports/ethics2.pdf https://doi.org/10.4018/978-1-59140-152-0. ch002

(Luettu 1.5.2020.)

Merikukka, Marko \& Ristikari, Tiina \& Kiilakoski, Tommi (2019). Suojaako yläkouluikäisten nuorten osallisuuden kokemus koulussa lyhyeltä koulutuspolulta? Yhteiskuntapolitiikka, 84(4), 403-415.

Meriluoto, Taina (2018). Making Experts-byExperience: Governmental Ethnography of Participatory Initiatives in Finnish Social Welfare Organisations. Jyväskylä: University of Jyväskylä.

Meriläinen, Mikko (2020). Kohti pelisivistystä: Nuorten digitaalinen pelaaminen ja pelihaitat kotien kasvatuskysymyksenä. Kasvatustieteellisiä tutkimuksia, numero 66, Helsingin yliopisto, Helsinki.

Nelimarkka, Matti (2019). Aihemallinnus sekä muut ohjaamattomat koneoppimismenetelmät yhteiskuntatieteellisessä tutkimuksessa: kriittisiä havaintoja. Politiikka, 61(1), 6-33.

Oberst, Ursula \& Wegmann, Elisa \& Stodt, Benjamin \& Brand, Matthias \& Chamarro, Andrés (2017). Negative consequences from heavy social networking in adolescents: The mediating role of fear of missing out. Journal of Adolescence, 55, 51-60.

https://doi.org/10.1016/j.adoles-

cence.2016.12.008

OECD (2019). Recommendation of the Council on Artificial Intelligence. OECD/LEGAL/0449.

OECD Observatory of Public Sector Innovation (2017). Embracing Innovation in Government Global Trends. February 2017. OECD Publishing, Paris.

Opetus- ja kulttuuriministeriö (2020). Valtakunnallisen nuorisotyön ja -politiikan ohjelma 2020 2023. Opetus- ja kulttuuriministeriön julkaisuja 2020:2, Helsinki.

Osborne, Stephen, P. (2018). From public service-dominant logic to public service logic: are public service organizations capable of co-production and value co-creation? Public Management Review, 20(2), 225-231. https://doi.org/10.1080/14719037.2017.1350461

Pernaa, Hanna-Kaisa (2020). Hyvinvoinnin toivottu tulevaisuus: tarkastelussa kompleksisuus, antisipaatio ja osallisuus. Acta Wasaensia 443, Vaasan yliopisto.

Pohjola, Anneli (2001) Nuorten myyttinen ongelmallisuus. Teoksessa Suutari, Minna (toim.) Vallattomat marginaalit. Yhteisöllisyyksiä nuoruudessa ja yhteiskunnan reunoilla, 187-204, Nuorisotutkimusverkosto/Nuorisotutkimusseura, julkaisuja 20, Helsinki.

Puschmann, Cornelius \& Scheffer, Tatjana (2016) Topic modelling for media and communication research: a short primer. HIIG Discussion Paper Series No. 2016-05. http://dx.doi.org/10.2139/ssrn.2836478

Raisio, Harri \& Valkama, Katja \& Peltola Elina (2014). Disability and deliberative democracy: towards involving the whole human spectrum in public deliberation. Scandinavian Journal of Disability Research, (6)1, 77-97.

http://doi.org/10.1080/15017419.2013.781957

Ransbotham, Sam \& Fichman, Robert, G. \& Gopal, Ram \& Gupta, Alok (2016). Special section introduction-ubiquitous IT and digitalvulnerabilities. Information Systems Research, 27(4), 834-847. https://doi.org/10.1287/isre.2016.0683

Reich, Stephanie, M. (2010). Adolescents' sense of community on MySpace and Facebook: A mixed-method approach. Journal of Community Psychology, 38(6), 688-705. https://doi.org/10.1002/jcop.20389

Robinson, Jo \& Cox, Georgina \& Bailey, Eleanor \& Hetrick, Sarah \& Rodrigues, Maria \& Fisher, Steve \& Herrman, Helen (2016). Social media and suicide prevention: a systematic review. 
Early Intervention in Psychiatry, 10(2), 103-121. https://doi.org/10.1111/eip.12229

Seko, Yakari \& Kidd, Sean, A., Wiljer, David \& McKenzie, Kwame, J. (2015). On the creative edge: Exploring motivations for creating nonsuicidal self-injury content online. Qualitative Health Research, 25(10), 1334-1346.

DOI: $10.1177 / 1049732315570134$

Steen, Trui \& Tuurnas, Sanna (2018) The roles of the professional in co-production and co-creation processes. Teoksessa Brandsen, Taco, Steen, Trui \& Verschuere, Bram (toim.) Co-production and Co-creation. Engaging Citizens in Public Services, 80-92. Routledge, London.

Sunstein, Cass (2017). \#Republic Divided Democracy in the Age of Social Media. Princeton University Press, New Jersey. https://doi.org/10.2307/j.ctv8xnhtd

Suoninen, Eero (2016). Kielenkäytön vaihtelevuuden analysoiminen. Teoksessa Jokinen, Arja \& Juhila, Kirsi \& Suoninen, Eero (toim.) Diskurssianalyysi - Teoriat, peruskäsitteet ja käyttö. Vastapaino, Tampere.

Suutari, Minna (toim.) (2001). Vallattomat marginaalit. Yhteisöllisyyksiä nuoruudessajayhteiskunnan reunoilla. Nuorisotutkimusverkosto/Nuorisotutkimusseura, julkaisuja 20, Helsinki.

Tilastokeskus (2017). Vapaa-ajan osallistuminen. http://tilastokeskus.fi/til/vpa/index.html (Luettu 20.12.2020.)

Toivanen, Pihla \& Huhtamäki, Jukka \& Valaskivi, Katja \& Tikka, Minttu (2020). Aihemallinnus hybridin mediatapahtuman ja merkitysten kierron tutkimuksessa. Media \& Viestintä, 43(1), 1-20. https://doi.org/10.23983/mv.91078

Toivonen, Timo (1999). Empiirinen sosiaalitutkimus. Filosofia ja metodologia. WSOY, Juva.

Vainikka, Eliisa \& Harju, Auli (2019). Anonyymien keskustelupalstojen julkisuus. Marginaaliin jääneiden vertaistukea ja yhteiskuntakritiikkiä. Media \& Viestintä, 42(2), 99-121. https://doi.org/10.23983/mv.83374

Vakkala, Hanna \& Syväjärvi, Antti (2020). Tietokulttuurin ulottuvuudet sosiaali- ja terveydenhuollon uudistuvissa organisaatioissa - vuorovaikutteisen tiedolla johtamisen haaste. Hallinnon Tutkimus, 39(2), 122-139.

https://doi.org/10.37450/ht.98085
Valkenburg, Patti, M. \& Peter, Jochen (2009). The effects of instant messaging on the quality of adolescents' existing friendships: A longitudinal study. Journal of Communication, 59(1), 79-97. https://doi.org/10.1111/j.1460-

2466.2008.01405.x

Valtioneuvoston kanslia (2019). Algoritmi päätöksentekijänä? Tekoälyn hyödyntämisen mahdollisuudet ja haasteet kansallisessa sääntely-ympäristössä. Valtioneuvoston selvitys- ja tutkimustoiminnan julkaisusarja 44/2109, Helsinki.

Vanttaja, Markku \& Af Ursin Piia \& Järvinen, Tero (2019) Kouluun sitoutumattomien nuorten tausta ja tulevaisuusodotukset. Yhteiskuntapolitiikka, 84(5-6), 491-503.

Vargo, Stephen, L. \& Lusch, Robert, F. (2017) Service-dominant logic 2025. International Journal of Research in Marketing, 34(1), 46-67. https://doi.org/10.1016/j.ijresmar.2016.11.001

Voorberg, William, H. \& Bekkers, Victor, J. J. M. \& Tummers, Lars, G. (2014). A systematic review of co-creation and co-production: embarking on the social innovation journey. Public Management Review, 17(9), 1333-1357. https://doi.org/10.1080/14719037.2014.930505

Vosoughi, Soroush \& Roy, Deb \& Aral, Sinan (2018). The spread of true and false news online. Science, (359)6380, 1146-1151.

https://doi.org/10.1126/science.aap9559

Weinstein, Emily, C. (2014). The personal is political on social media: Online civic expression patterns and pathways among civically engaged youth. International Journal of Communication, $8,210-233$

Woolley, Samuel, C. \& Howard, Philip, N. (2018). Computational Propaganda. Political Parties, Politicians, and Political Manipulation on Social Media. Oxford University Press, Oxford.

https://doi.org/10.1093/ oso/9780190931407.001.0001

Yang, Chia-chen, \& Brown, Bradford, B. (2013). Motives for using Facebook, patterns of Facebook activities, and late adolescents' social adjustment to college. Journal of Youth and Adolescence, 42(3), 403-416. https://doi.org/10.1007/s10964-012-9836-x 
Liite 1.

SOSIAALISEN MEDIAN HYÖDYNTÄMINEN PALVELUJEN YHTEISKEHITTÄMISESSÄ

\section{Teemojen määrän määrittely kaikissa viesteissä}

\begin{tabular}{|l|l|l|l|l|}
\hline teemojen määrä & Griffiths2004 & CaoJuan2009 & Arun2010 & Deveaud2014 \\
\hline 2 & -413189.8 & 0.05207234 & 2800.010 & 2.662396 \\
\hline 3 & -392841.3 & 0.06310903 & 2599.247 & 2.601560 \\
\hline 4 & -381438.1 & 0.04895806 & 2455.969 & 2.592959 \\
\hline 5 & -370926.7 & 0.05202274 & 2350.191 & 2.558961 \\
\hline 6 & -363997.6 & 0.04359119 & 2254.581 & 2.561207 \\
\hline 7 & -358434.6 & 0.03801782 & 2173.783 & 2.550152 \\
\hline 8 & -356168.9 & 0.04152681 & 2114.149 & 2.528784 \\
\hline 9 & -349520.8 & 0.04652782 & 2064.476 & 2.507224 \\
\hline 10 & -349209.4 & 0.04024766 & 2006.097 & 2.486549 \\
\hline
\end{tabular}

\section{Teemojen määrän määrittely negatiivisissa viesteissä}

\begin{tabular}{|l|l|l|l|l|}
\hline teemojen määrä & Griffiths2004 & CaoJuan2009 & Arun2010 & Deveaud2014 \\
\hline 2 & -189266.5 & 0.04409785 & 3563.746 & 2.591690 \\
\hline 3 & -180603.2 & 0.05093707 & 3304.853 & 2.531278 \\
\hline 4 & -173851.8 & 0.05939551 & 3132.674 & 2.461443 \\
\hline 5 & -170388.1 & 0.04363732 & 2984.085 & 2.526094 \\
\hline 6 & -167305.7 & 0.04584996 & 2872.755 & 2.473483 \\
\hline 7 & -163433.3 & 0.04808042 & 2782.769 & 2.440567 \\
\hline 8 & -161566.8 & 0.04360709 & 2695.616 & 2.428754 \\
\hline 9 & -160271.6 & 0.04147533 & 2622.406 & 2.432945 \\
\hline 10 & -158343.3 & 0.04617000 & 2571.106 & 2.395541 \\
\hline
\end{tabular}

\section{Kaikkien viestien varianssianalyysi}

\begin{tabular}{|c|c|c|c|c|c|c|}
\hline \multicolumn{7}{|c|}{ Varianssianalyysi (ANOVA) kaikkien teemojen välillä } \\
\hline & SS & $d f$ & MS & $\mathrm{F}$ & Prob $>\mathrm{F}$ & $\mathrm{N}$ \\
\hline Teema 1 & 16097.7725 & 3 & 5365.92416 & 58.81 & $.00 * * *$ & 803 \\
\hline Teema 2 & 6625.77239 & 3 & 2208.5908 & 27.62 & $.00 * * *$ & 822 \\
\hline Teema 3 & 5339.65959 & 3 & 1779.88653 & 19.92 & $.00 * * *$ & 753 \\
\hline Teema 4 & 14588.7847 & 3 & 4862.92823 & 47.96 & $.00 * * *$ & 728 \\
\hline
\end{tabular}

* tilastollisesti merkitsevä .10 tasolla

** tilastollisesti merkitsevä .05 tasolla

$\star * \star$ tilastollisesti merkitsevä 01 tasolla 
Bartlett'n testi varianssien yhtäsuuruudesta kaikissa viesteissä

\begin{tabular}{|l|l|l|}
\hline & chi2(3) & Prob>chi2 \\
\hline Teema 1 & 497.6442 & $.00 * * *$ \\
\hline Teema 2 & 118.9233 & $.00 * * *$ \\
\hline Teema 3 & 183.9940 & $.00 * * *$ \\
\hline Teema 4 & 379.9907 & $.00 * * *$ \\
\hline
\end{tabular}

* tilastollisesti merkitsevä .10 tasolla

** tilastollisesti merkitsevä .05 tasolla

*** tilastollisesti merkitsevä .01 tasolla

\section{Negatiivisten viestien varianssianalyysi}

\begin{tabular}{|l|l|l|l|l|l|l|}
\hline \multicolumn{2}{|l}{ Varianssianalyysi (ANOVA) negatiivisten viestien osalta kolmessa teemassa } \\
\hline & SS & df & MS & F & Prob $>$ F & N \\
\hline Teema 1 & 6122.76125 & 2 & 3061.38063 & 48.48 & $.00 * * *$ & 528 \\
\hline Teema 2 & 2362.70096 & 2 & 1181.35048 & 22.58 & $.00 * * *$ & 491 \\
\hline Teema 3 & 3800.20716 & 2 & 1900.10358 & 34.98 & $.00 * * *$ & 515 \\
\hline
\end{tabular}

* tilastollisesti merkitsevä .10 tasolla

** tilastollisesti merkitsevä .05 tasolla

*** tilastollisesti merkitsevä .01 tasolla

Bartlett'n testi varianssien yhtäsuuruudesta negatiivisissa viesteissä

\begin{tabular}{|l|l|l|}
\hline & chi2(2) & Prob>chi2 \\
\hline Teema 1 & 156.4093 & $.00 * \star \star$ \\
\hline Teema 2 & 33.8816 & $.00 * * *$ \\
\hline Teema 3 & 41.3105 & $.00 * * *$ \\
\hline
\end{tabular}

* tilastollisesti merkitsevä .10 tasolla

** tilastollisesti merkitsevä .05 tasolla

*** tilastollisesti merkitsevä .01 tasolla 
Kaikkien viestien teemoittainen sentimenttianalyysi

\begin{tabular}{|l|l|l|l|l|l|}
\hline & Teema 1 & Teema 2 & Teema 3 & Teema 4 & sig. \\
\hline viha & 1.13 & 1.60 & 1.33 & 1.35 & $.00 * * *$ \\
\hline odotus & 2.37 & 2.66 & 2.33 & 2.67 & $.01 * *$ \\
\hline inho & 0.75 & 1.16 & 0.87 & 0.95 & $.00 * * *$ \\
\hline pelko & 1.58 & 2.33 & 1.69 & 2.06 & $.00 * * *$ \\
\hline ilo & 1.23 & 1.87 & 1.47 & 1.56 & $.00 * * *$ \\
\hline suru & 1.64 & 2.14 & 1.77 & 2.06 & $.00 * * *$ \\
\hline yllätys & 0.86 & 1.15 & 0.94 & 1.01 & $.00 * * *$ \\
\hline luottamus & 2.57 & 3.31 & 2.66 & 3.02 & $.00 * * *$ \\
\hline negatiivinen & 2.82 & 3.69 & 3.11 & 3.51 & $.00 * * *$ \\
\hline positiivinen & 4.42 & 5.29 & 4.62 & 5.06 & $.00 * * *$ \\
\hline
\end{tabular}

* tilastollisesti merkitsevä .10 tasolla

** tilastollisesti merkitsevä .05 tasolla

$\star * \star$ tilastollisesti merkitsevä 01 tasolla

\section{Negatiivisten viestien teemoittainen sentimenttianalyysi}

\begin{tabular}{|l|l|l|l|l|}
\hline & Teema 1 & Teema 2 & Teema 3 & sig. \\
\hline viha & 1.91 & 1.95 & 1.89 & ei \\
\hline odotus & 3.00 & 2.30 & 2.68 & $.00 * * *$ \\
\hline inho & 1.26 & 1.20 & 1.16 & ei \\
\hline pelko & 2.72 & 2.19 & 2.59 & $.00 * * *$ \\
\hline ilo & 1.70 & 1.45 & 1.53 & $.05 *$ \\
\hline suru & 2.49 & 2.06 & 2.44 & $.00 * * *$ \\
\hline yllätys & 1.26 & 1.13 & 1.21 & ei \\
\hline luottamus & 3.04 & 2.57 & 2.97 & $.00 * * *$ \\
\hline negatiivinen & 4.36 & 3.96 & 4.53 & $.03 * *$ \\
\hline positiivinen & 4.86 & 4.25 & 4.53 & $.03 * *$ \\
\hline
\end{tabular}

* tilastollisesti merkitsevä .10 tasolla

** tilastollisesti merkitsevä .05 tasolla

*** tilastollisesti merkitsevä .01 tasolla 